\title{
Effect of Equal-Channel Angular Pressing on Pitting Corrosion of Pure Aluminum
}

\author{
Injoon Son, ${ }^{1}$ Hiroaki Nakano, ${ }^{2}$ Satoshi Oue, ${ }^{2}$ Shigeo Kobayashi, ${ }^{3}$ \\ Hisaaki Fukushima, ${ }^{2}$ and Zenji Horita ${ }^{2}$ \\ ${ }^{1}$ Department of Materials Science and Metallurgy, Kyungpook National University, 1370 Sangyeok-dong, Buk-gu, \\ Daegu 702-701, Republic of Korea \\ ${ }^{2}$ Department of Materials Science and Engineering, Kyushu University, 744 Motooka, Nishi-ku, Fukuoka 819-0395, Japan \\ ${ }^{3}$ Department of Applied Chemistry and Biochemistry, Kyushu Sangyo University, 2-3-1 Matsukadai, Higashi-ku, \\ Fukuoka 813-8503, Japan \\ Correspondence should be addressed to Hiroaki Nakano,nakano@zaiko.kyushu-u.ac.jp
}

Received 25 November 2011; Revised 20 February 2012; Accepted 20 February 2012

Academic Editor: Flavio Deflorian

Copyright (C) 2012 Injoon Son et al. This is an open access article distributed under the Creative Commons Attribution License, which permits unrestricted use, distribution, and reproduction in any medium, provided the original work is properly cited.

The effect of equal-channel angular pressing (ECAP) on the pitting corrosion of pure Al was investigated using electrochemical techniques in solutions containing $0.1 \mathrm{~m} \mathrm{~mol} \cdot \mathrm{dm}^{-3}$ of $\mathrm{Na}_{2} \mathrm{SO}_{4}$ and $8.46 \mathrm{~mol} \cdot \mathrm{dm}^{-3}$ of $\mathrm{NaCl}\left(300 \mathrm{ppm} \mathrm{Cl}{ }^{-}\right)$and followed by surface analysis. The potential for pitting corrosion of pure $\mathrm{Al}$ was clearly shifted in the noble direction by the ECAP process indicating that this process improves resistance to pitting corrosion. The time dependence of corrosion potential and the anodic potential at $1 \mathrm{~A} \cdot \mathrm{m}^{-2}$ revealed that the rate of formation of $\mathrm{Al}$ oxide films increased due to a decrease in the grain size of the Al after ECAP. Since there exists a negligible amount of impurity precipitates in pure Al, the improvement in pitting corrosion resistance of pure $\mathrm{Al}$ by ECAP appears to be attributable to an increase in the rate of formation of Al oxide films.

\section{Introduction}

Although aluminum is inherently an active metal, it shows excellent corrosion resistance over a neutral $\mathrm{pH}$ range of $4-8$ due to its superficial oxide film. In solutions containing $\mathrm{Cl}^{-}$, however, pitting corrosion occurs locally where the oxide film is attacked by $\mathrm{Cl}^{-}$[1-7]. On the other hand, reducing the grain size of metallic materials to the submicron range or even the nanometer range using equal-channel angular pressing (ECAP), high pressure torsion (HPT), or severe torsion straining processing (STSP) is increasingly being studied with the aim of improving mechanical properties such as strength and ductility [8-13]. Although the literature is reasonably scarce with investigations reporting the effects of severe plastic deformation upon the pitting and general corrosion behaviour [14-20] of Al-based alloys, mainly AA1100 and AA5052 (Al-Mg), those reported their majority suggests that corrosion resistance decreases with decreasing the grain size $[14,15]$. It should also be remarked that chloride content, $\mathrm{pH}$ and other characteristics and nature of solution significantly affect the corrosion behaviour. Considering the ECAP, it has been reported both increase and decrease on the corrosion resistance $[15,17,18]$. Ralston et al. [15] recently reported that finer grains of commercially pure (c.p.) grade Al samples provide significant gains into the corrosion resistance in acidic and alkaline sodium chloride media whilst having lesser, but noticeable, impact in near neutral electrolytes [15]. It was also reported [15] that ECAP has provided low corrosion rates by using a single cast ingot of ultrahigh purity Al. Precipitate compounds of Fe-Al and Si were found around the pitting area. Because the corrosion potential of the precipitates is nobler than the $\mathrm{Al}$ matrix, the pitting corrosion of $\mathrm{Al}$ seems to occur forming local cells where precipitates act as cathodes. The improvement in pitting corrosion resistance from ECAP seems to be attributable to both a decrease in the size of precipitates, which act as cathodes during pitting corrosion, and an increase in the rate of formation of Al oxide films due to the reduction of the grain size of $\mathrm{Al}$. However, the reason for improvement of the pitting corrosion resistance of $\mathrm{Al}$ alloys with ECAP was not made clear. 


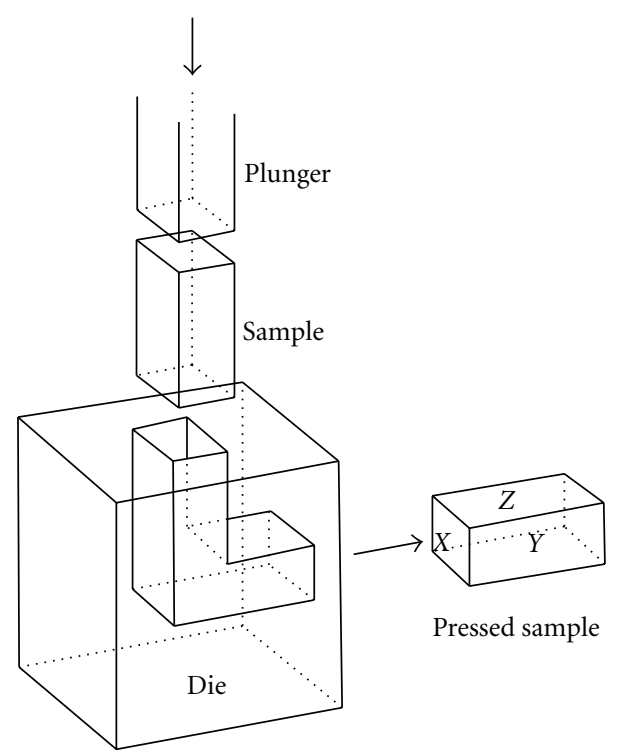

FIgURE 1: Schematic diagram of ECAP.

In this study, pure $\mathrm{Al}$ of $4 \mathrm{~N}$ (>99.99 mass\%) without precipitates was used to determine whether the increase in the formation rate of $\mathrm{Al}$ oxide films contributes to the improvement of the pitting corrosion resistance in $\mathrm{Al}$ or not. The effect of ECAP on the pitting corrosion of pure $\mathrm{Al}$ and anodized pure Al was investigated. The pitting behaviour of Al was investigated using electrochemical techniques. In addition, the reason for the improvement in the pitting corrosion resistance of $\mathrm{Al}$ with ECAP was further analyzed using surface analysis techniques.

\section{Experimental}

Pure Al (>99.99 mass\%) was used as experimental specimens. Figure 1 shows a schematic diagram of the ECAP process. ECAP was conducted for eight passes at room temperature $\left(20-25^{\circ} \mathrm{C}\right)$ using a die with a channel angle of $90^{\circ}$ (error range $< \pm 0.01^{\circ}$ ) which creates an equivalent strain of about 1 during one passage through the die. The samples were rotated $90^{\circ}$ about the longitudinal axis in the same sense between consecutive passes, the generally designated processing route $\mathrm{Bc}[11]$. Each press was performed at a rate of $\sim 19 \mathrm{~mm} \cdot \mathrm{s}^{-1}$ using $\mathrm{MoS}_{2}$ as a lubricant. The initial average grain size of $\mathrm{Al}$ prior to ECAP was $30-50 \mu \mathrm{m}$. The average grain size of $\mathrm{Al}$ after the ECAP process was confirmed by TEM observation to be $0.5-1.0 \mu \mathrm{m}$ [21].

Specimens of $1.0 \mathrm{~cm}$ in diameter were prepared for corrosion testing. Their corrosion resistance was investigated over an area $28.26 \mathrm{~mm}^{2}$; the remaining area was sealed with waterproof tape to prevent any corrosion due to edge effects. After pure Al was carefully polished down with No. 600 emery paper, it was immersed in a solution containing $0.1 \mathrm{~mol} \cdot \mathrm{dm}^{-3}$ of $\mathrm{Na}_{2} \mathrm{SO}_{4}$ and $8.46 \mathrm{mmol} \cdot \mathrm{dm}^{-3}$ of $\mathrm{NaCl}$ $\left(300 \mathrm{ppm} \mathrm{Cl}^{-}\right)$at $25^{\circ} \mathrm{C}$ for one hour in an air atmosphere. Potentiodynamic polarization curves were measured by polarizing from the less noble potential to the anodic potential direction using the potential sweep method at $0.5 \mathrm{mV} \cdot \mathrm{s}^{-1}$. In addition, the time dependence of anodic current density was measured while being maintained at $0.3 \mathrm{~V}$ versus NHE after immersion for 60 minutes. The electrode potentials were measured using a saturated $\mathrm{KCl}, \mathrm{Ag} / \mathrm{AgCl}$ reference electrode $\left(0.197 \mathrm{~V}\right.$ versus $\left.\mathrm{NHE}, 25^{\circ} \mathrm{C}\right)$. Since mercury is contained in calomel electrode, $\mathrm{Ag} / \mathrm{AgCl}$ electrode was used as reference electrode in this study. Polarization curve potentials were plotted with reference to NHE. Platinum was used as the counterelectrode in all electrochemical measurements.

Since the naturally formed $\mathrm{Al}$ oxide films were of the barrier type, the time dependence of anodic potentials was examined during galvanostatic electrolysis at $1 \mathrm{~A} \cdot \mathrm{m}^{-2}$ in a solution containing $0.5 \mathrm{~mol} \cdot \mathrm{dm}^{-3}$ of $\mathrm{H}_{3} \mathrm{BO}_{3}$ and $0.05 \mathrm{~mol} \cdot \mathrm{dm}^{-3}$ of $\mathrm{Na}_{2} \mathrm{~B}_{4} \mathrm{O}_{7} \cdot 10 \mathrm{H}_{2} \mathrm{O}$ used to form a barriertype oxide film $[22,23]$. The effect of ECAP on the rate of formation of the $\mathrm{Al}$ oxide film was assumed to be revealed by the time dependence of the anode potentials.

Prior to anodizing, pure $\mathrm{Al}$ was carefully polished down with No. 1500 emery paper and immersed in a $0.75 \mathrm{~mol} \cdot \mathrm{dm}^{-3} \mathrm{NaOH}$ solution at $25^{\circ} \mathrm{C}$ for $30 \mathrm{~s}$, after which they were neutralized in $0.48 \mathrm{~mol} \cdot \mathrm{dm}^{-3}$ of $\mathrm{HNO}_{3}$ solution for $30 \mathrm{~s}$ and electropolished in a $20^{\circ} \mathrm{C}$ solution containing methanol and perchloric acid $\left(\mathrm{MeOH}: \mathrm{HClO}_{4}=4: 1\right)$ at $10 \mathrm{~V}$ for $5 \mathrm{~min}$. Anodizing was conducted in a solution containing $1.53 \mathrm{~mol} \cdot \mathrm{dm}^{-3}$ of $\mathrm{H}_{2} \mathrm{SO}_{4}$ and $0.0185 \mathrm{~mol} \cdot \mathrm{dm}^{-3}$ of $\mathrm{Al}_{2}\left(\mathrm{SO}_{4}\right)_{3} \cdot 16 \mathrm{H}_{2} \mathrm{O}$ at $20^{\circ} \mathrm{C}$ under galvanostatic conditions of three different current densities, that is, 100, 200, and $400 \mathrm{~A} \cdot \mathrm{m}^{-2}$ for 20 minutes while agitated at $100 \mathrm{rpm}$ using a magnetic stirrer. The time dependence of anodic current density was measured while the system was maintained at $1.2 \mathrm{~V}$ after immersion for $30 \mathrm{~min}$ in a $0.2 \mathrm{~mol} \cdot \mathrm{dm}^{-3} \mathrm{AlCl}_{3}$ solution with a $\mathrm{pH}$ of 2.8 at $25^{\circ} \mathrm{C}$.

The morphology of $\mathrm{Al}$ with and without ECAP was observed using SEM after electrolytic polishing. Pitting corrosion occurred while the samples were held at $0.3 \mathrm{~V}$ for $5 \mathrm{~min}$ in a solution containing $0.1 \mathrm{~mol} \cdot \mathrm{dm}^{-3}$ of $\mathrm{Na}_{2} \mathrm{SO}_{4}$ and $8.46 \mathrm{mmol} \cdot \mathrm{dm}^{-3}$ of $\mathrm{NaCl}$; SEM micrographs were also obtained in order to microstructural observations.

\section{Results and Discussion}

3.1. Effect of ECAP on the Pitting Corrosion of Pure Al. Figure 2 shows the effect of ECAP on the potentiodynamic polarization curve of pure $\mathrm{Al}$. In all figures below, the reported results [20] of AA1100 (mass $\%$, >99.0\% Al, 0.15\% $\mathrm{Cu}, 0.09 \% \mathrm{Si}, 0.60 \% \mathrm{Fe}, 0.005 \% \mathrm{Mn}, 0.006 \% \mathrm{Zn}, 0.002 \% \mathrm{Mg}$, $<0.001 \% \mathrm{Cr}$ ) were also shown to compare with pure $\mathrm{Al}$. The anode current densities of pure $\mathrm{Al}$ and $\mathrm{Al}$ (AA1100) rapidly increased at certain potentials when the anode potentials were shifted from their corrosion potentials in the noble direction. This rapid increase in current density is caused by initiation of pitting corrosion. The pitting corrosion potential, the point at which pitting corrosion is initiated, of pure $\mathrm{Al}$ as well as $\mathrm{Al}$ (AA1100) was shifted in the noble direction after application of ECAP, indicating improvement in the pitting corrosion resistance. On the other hand, the corrosion potential of pure $\mathrm{Al}$ was also slightly shifted in the 


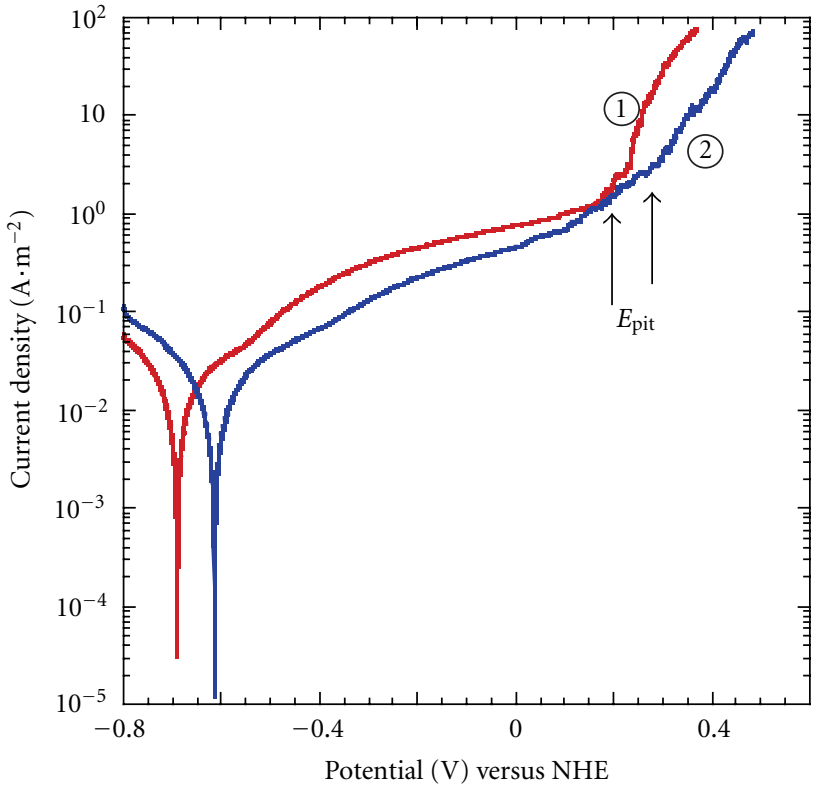

(1) Without ECAP

(2) With ECAP

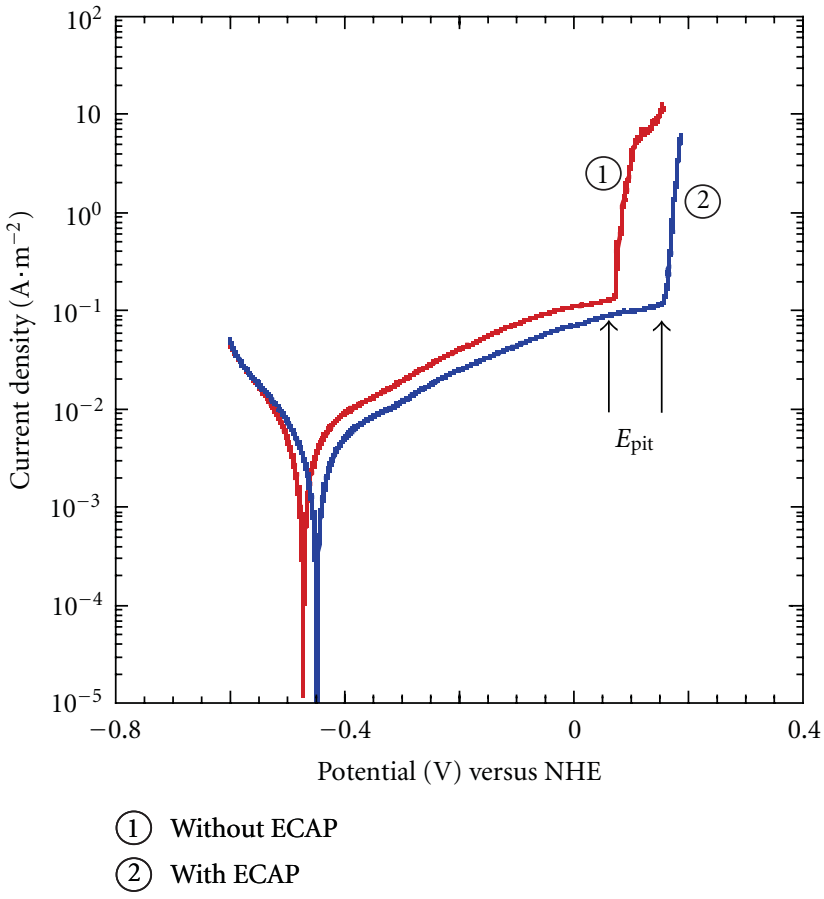

(b)

FIGURE 2: Effect of ECAP on the potentiodynamic polarization curves of pure $\mathrm{Al}$ (a) and Al (AA1100) (b) in a solution containing $0.1 \mathrm{~mol} \cdot \mathrm{dm}^{-3}$ of $\mathrm{Na}_{2} \mathrm{SO}_{4}$ and $300 \mathrm{ppm}$ of $\mathrm{Cl}^{-}$.

noble direction by ECAP. The pitting corrosion potential of pure $\mathrm{Al}$ was nobler than that of $\mathrm{Al}$ (AA1100). The current density needed to initiate pitting corrosion was larger for pure $\mathrm{Al}$ than for $\mathrm{Al}$ (AA1100), and the degree of increase in current density at the pitting corrosion potential was smaller for pure Al than for Al (AA1100). These results indicate that the pitting corrosion resistance of pure $\mathrm{Al}$ is better than that of Al (AA1100). It is known that the pitting potential can be coincident with the corrosion potential when the anodic Tafel slopes are practically zero (null), as previously reported $[24,25]$. It was demonstrated into the literature that, in a dilute sodium chloride solution $(0.01 \mathrm{M})$, the pitting corrosion potential of a commercially pure $\mathrm{Al}$ sample attains about $-545 \mathrm{mV}$ versus SCE [26]. It is clearly observed that both corrosion potential and pitting corrosion potential in this study are displaced to nobler-side potential than the literature, while passive current densities have considerably decreased since about 1 decade.

Figure 3 shows the time-dependence of the anodic current density of pure $\mathrm{Al}$ and $\mathrm{Al}$ (AA1100) while kept at constant potentials of, respectively, $0.3 \mathrm{~V}$ and $0.2 \mathrm{~V}$ nobler than their pitting corrosion potentials. The anode current density of pure Al increased sharply after a certain period of time due to the initiation of pitting corrosion. The time required before the initiation of pitting corrosion for pure $\mathrm{Al}$ was longer with ECAP than without; however, the degree of increase in time of pure $\mathrm{Al}$ with ECAP was smaller than that of $\mathrm{Al}$ (AA1100). Furthermore, the anodic current density after initiating pitting corrosion, or the growth rate of pitting corrosion, was smaller with ECAP than without for both pure $\mathrm{Al}$ as well as $\mathrm{Al}$ (AA1100).

Figure 4 shows the morphology of pure $\mathrm{Al}$ after a $5 \mathrm{~min}$ anodic reaction at $0.3 \mathrm{~V}$ nobler than the pitting corrosion potential in a solution containing $0.1 \mathrm{~mol} \cdot \mathrm{dm}^{-3}$ of $\mathrm{Na}_{2} \mathrm{SO}_{4}$ and $8.46 \mathrm{mmol} \cdot \mathrm{dm}^{-3}$ of $\mathrm{NaCl}$. Crystallographic pits 100 $200 \mu \mathrm{m}$ in size were observed in both pure Al samples made with and without ECAP, as shown in Figures 4(a) and 4(c). This phenomenon can be seen from the enlarged pitting areas in Figures $4(\mathrm{~b})$ and $4(\mathrm{~d})$. Since the grain size of $\mathrm{Al}$ greatly decreased after ECAP, the crystals in the pitting area were more compact. Considering the typical faceted-type crystallographic morphology of the pits, which are shown in Figure 4, these evidenced pit morphology are slightly connected by filaments provoked by hydrogen evolution $[24,27$, $28]$ and it seems that they increase with ECAP.

Figure 5 shows the morphology of electropolished pure $\mathrm{Al}$ and $\mathrm{Al}$ (AA1100) with and without ECAP. As shown in Figures 5(a) and 5(b), precipitates were observed in minute amounts in pure $\mathrm{Al}$, while many from $\mathrm{Fe}-\mathrm{Al}$ intermetallic compounds were observed in $\mathrm{Al}$ (AA1100) (Figures 5(c) and $5(\mathrm{~d})$ ). These precipitates were present in Al (AA1100) regardless of having undergone the ECAP process or not; however, the number of large precipitates in $\mathrm{Al}$ (AA1100) was greatly decreased due to an increase in small precipitates caused by ECAP. This phenomenon is shown by the arrow in Figure 5(d). Since the precipitates of impurities act as cathodes in the Al matrix, the precipitates nucleate causing the pitting corrosion of Al. Pitting corrosion is less likely to occur 


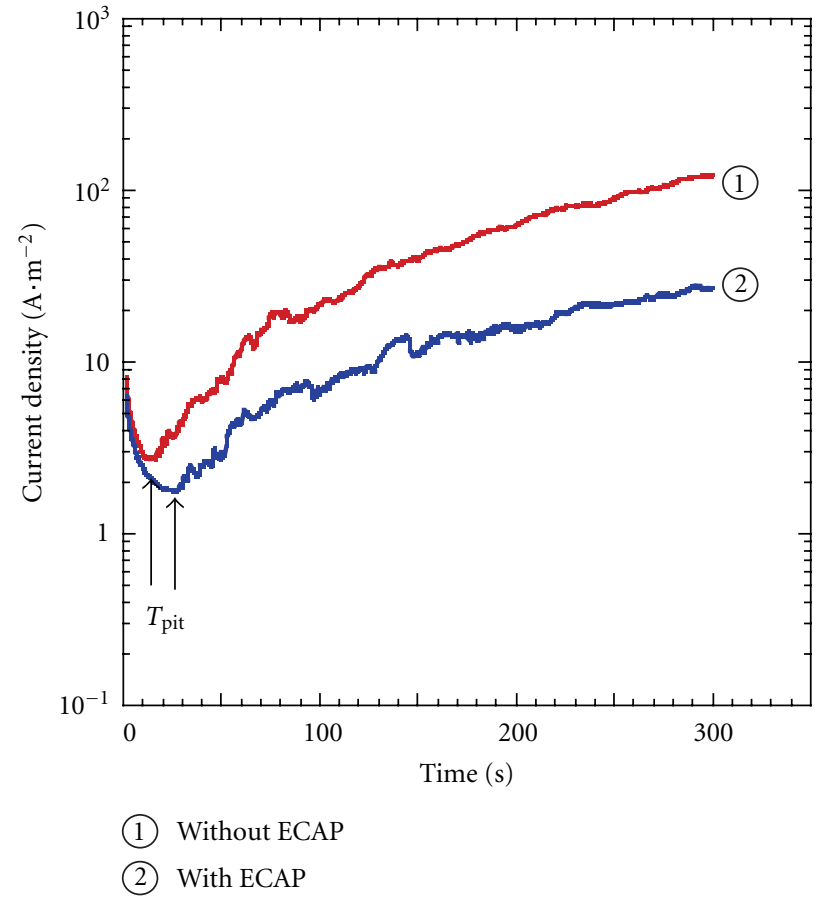

(a)

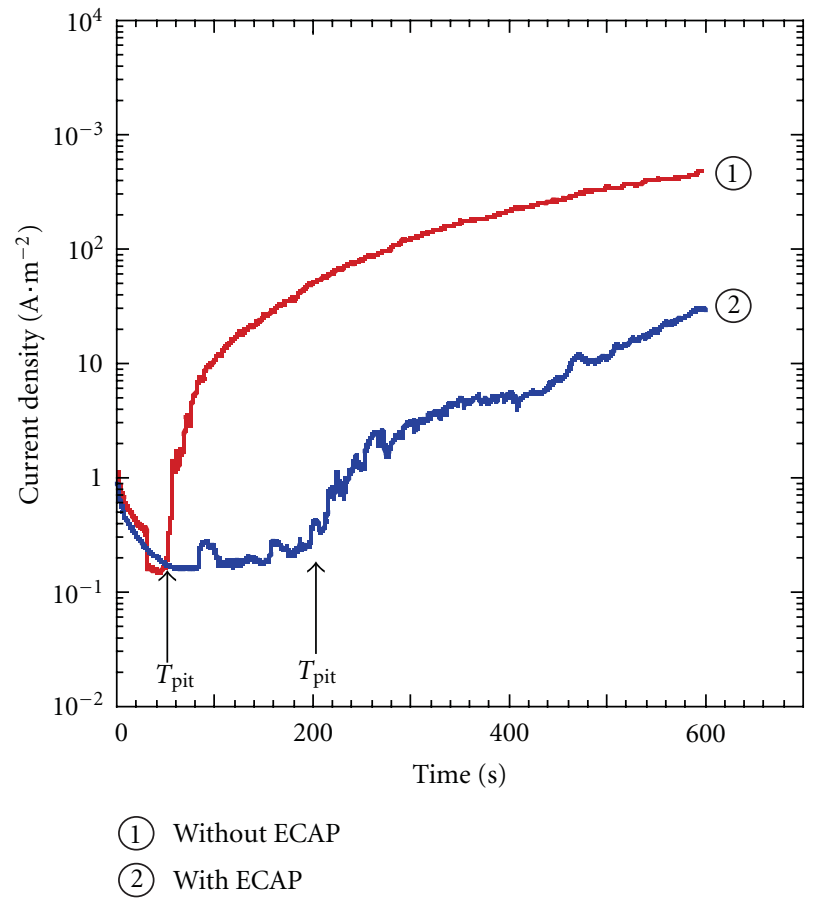

(b)

Figure 3: Time-dependence of the anodic current density of pure $\mathrm{Al}$ (a) and $\mathrm{Al}$ (AA1100) (b) while kept at constant potentials of, respectively, $0.3 \mathrm{~V}$ and $0.2 \mathrm{~V}$ nobler than their pitting corrosion potential in a solution containing $0.1 \mathrm{~mol} \cdot \mathrm{dm}^{-3} \mathrm{of} \mathrm{Na}_{2} \mathrm{SO}_{4}$ and $300 \mathrm{ppm}$ of $\mathrm{Cl}^{-}$.

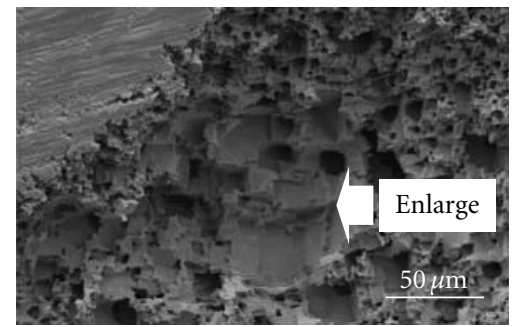

(a)

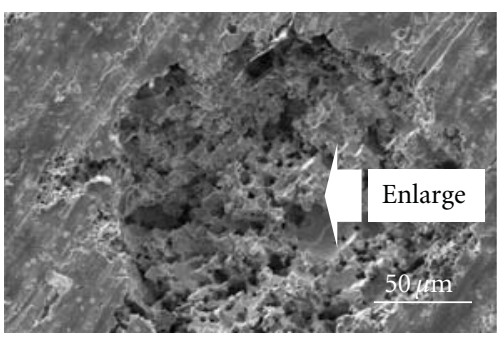

(c)

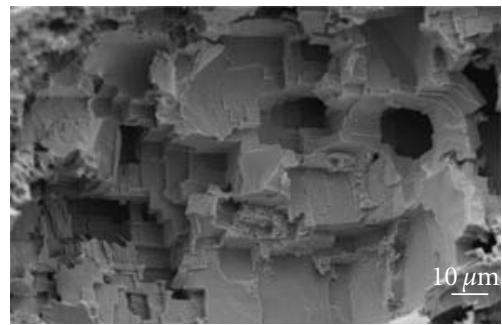

(b)

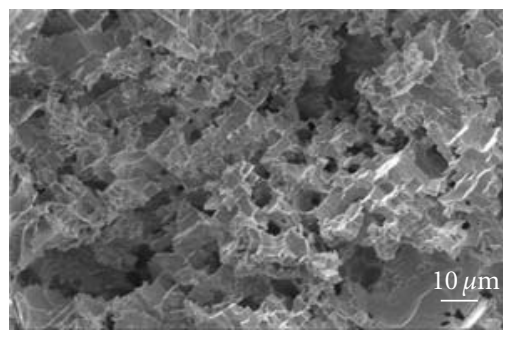

(d)

Figure 4: Morphology of $\mathrm{Al}$ after anodic oxidation for $5 \mathrm{~min}$ at $0.3 \mathrm{~V}$ nobler than the pitting corrosion potential in a solution containing $0.1 \mathrm{~mol} \cdot \mathrm{dm}^{-3}$ of $\mathrm{Na}_{2} \mathrm{SO}_{4}$ and $300 \mathrm{ppm}$ of $\mathrm{Cl}^{-}$. (a, b) Pure Al without ECAP. (c, d) Pure Al with ECAP.

with a decrease in the size of the precipitate, that is, with a decrease in cathode area. Only pits that grow readily around large precipitates during the initial stage seem to ultimately develop into macropits, this is attributed to the fact that most pits are unstable and are immediately repassivated [2]. The improvement of pitting corrosion resistance of $\mathrm{Al}$ (AA1100) with ECAP can thus be partially ascribed to a decrease in the size of the precipitates. However, the improvement of pitting corrosion resistance of pure $\mathrm{Al}$ with ECAP cannot be explained by a decrease in the size of the precipitates since pure $\mathrm{Al}$ contains only trace amounts of precipitates.

Figure 6 shows the time-dependence of the corrosion potential of pure $\mathrm{Al}$ and $\mathrm{Al}$ (AA1100) in a solution containing $0.1 \mathrm{~mol} \cdot \mathrm{dm}^{-3}$ of $\mathrm{Na}_{2} \mathrm{SO}_{4}$ and $300 \mathrm{ppm}$ of $\mathrm{Cl}^{-}$at $25^{\circ} \mathrm{C}$. The 


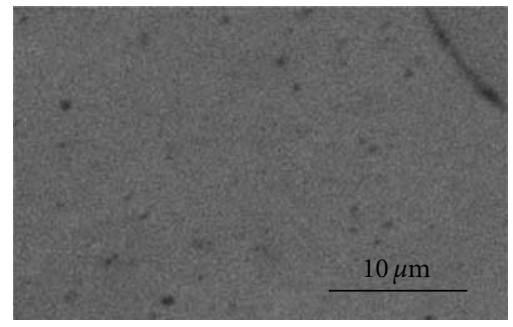

(a) Pure $\mathrm{Al}$ without ECAP

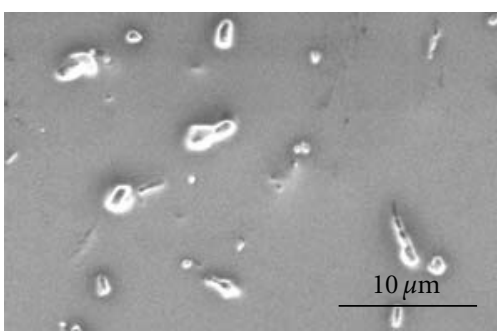

(c) $\mathrm{Al}(\mathrm{AA} 1100)$ without ECAP

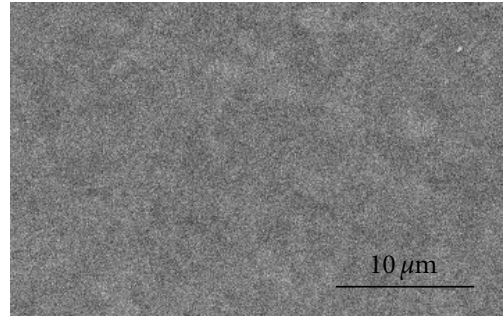

(b) Pure Al with ECAP

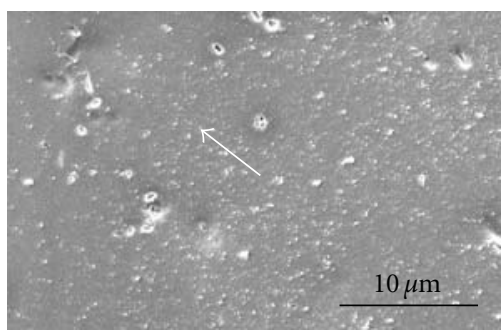

(d) $\mathrm{Al}(\mathrm{AA} 1100)$ with ECAP

Figure 5: Effect of ECAP on the morphology of pure $\mathrm{Al}$ and $\mathrm{Al}$ (AA1100).

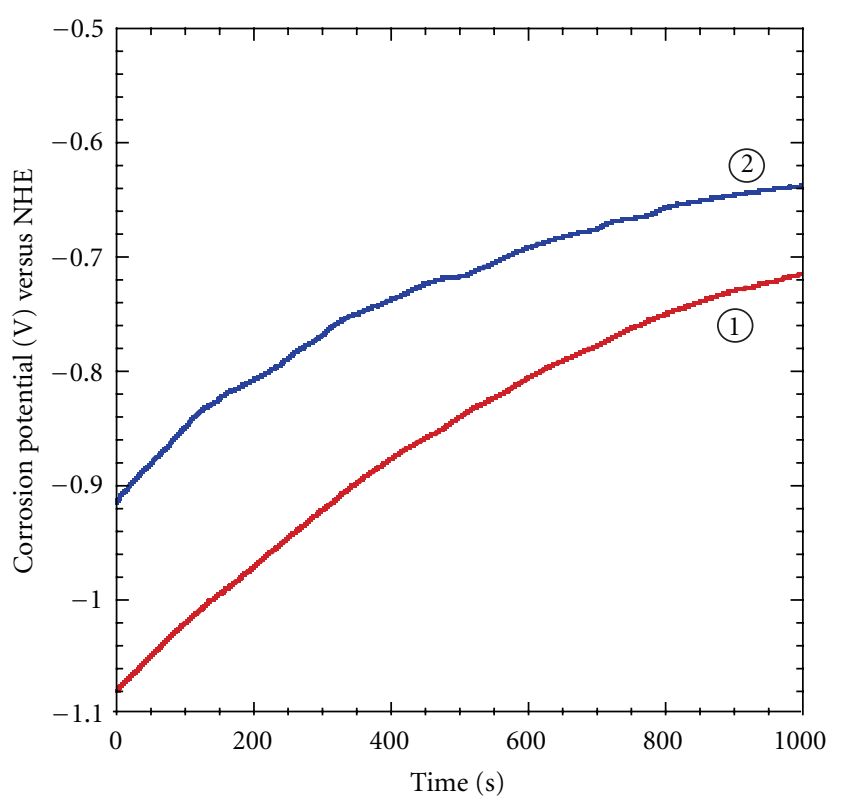

(1) Without ECAP

(2) With ECAP

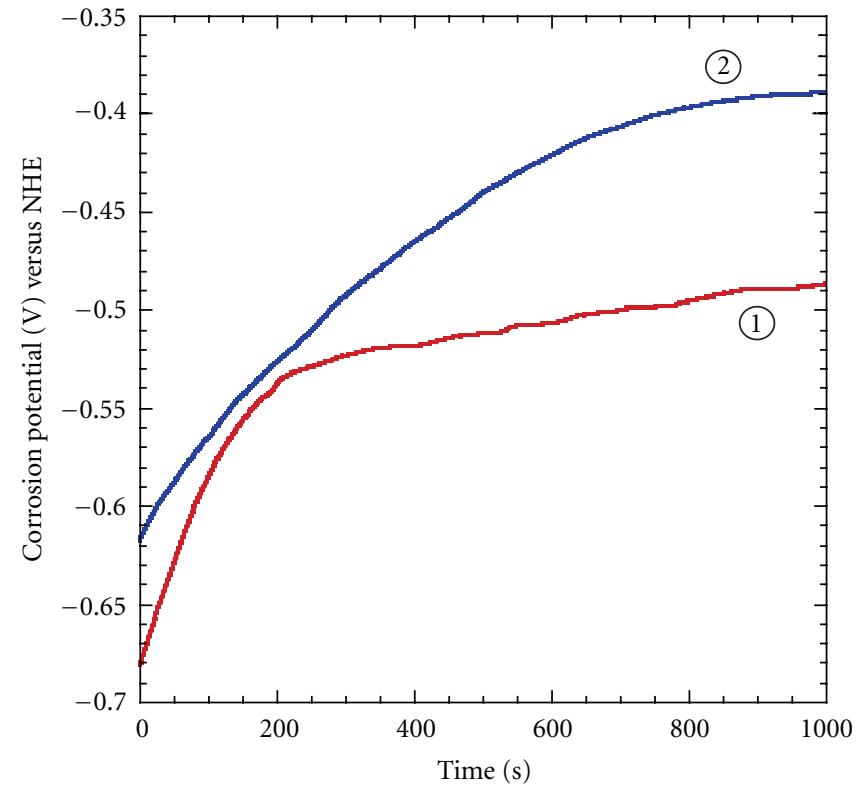

(1) Without ECAP

(2) With ECAP

(a)

(b)

FIgURE 6: Time-dependence of corrosion potential of pure $\mathrm{Al}$ (a) and $\mathrm{Al}(\mathrm{AA} 1100)$ (b) in a solution containing $0.1 \mathrm{~mol}^{\circ} \mathrm{dm}^{-3} \mathrm{of} \mathrm{Na}_{2} \mathrm{SO}_{4}$ and $300 \mathrm{ppm}$ of $\mathrm{Cl}^{-}$at $25^{\circ} \mathrm{C}$.

corrosion potential of pure $\mathrm{Al}$ shifted in the noble direction with increased time. This can be ascribed to the $\mathrm{Al}$ oxide film that naturally forms in the solution. The corrosion potential of pure $\mathrm{Al}$ shifted in the noble direction more rapidly with ECAP than without, suggesting that the rate of formation of $\mathrm{Al}$ oxide film increased with ECAP. It is well known that the oxidation of metal occurs more rapidly at crystalline lattice defects such as grain boundaries and dislocations [1, 2]. The ECAP process markedly increases the number of grain boundaries and the dislocation density in Al. The oxidation rate of $\mathrm{Al}$ appears to increase as a result of the increase in grain boundaries and dislocation density caused by ECAP. The oxidation rate of $\mathrm{Al}$ (AA1100) is faster than that of pure Al because the impurities contained in $\mathrm{Al}$ (AA1100) segregate 


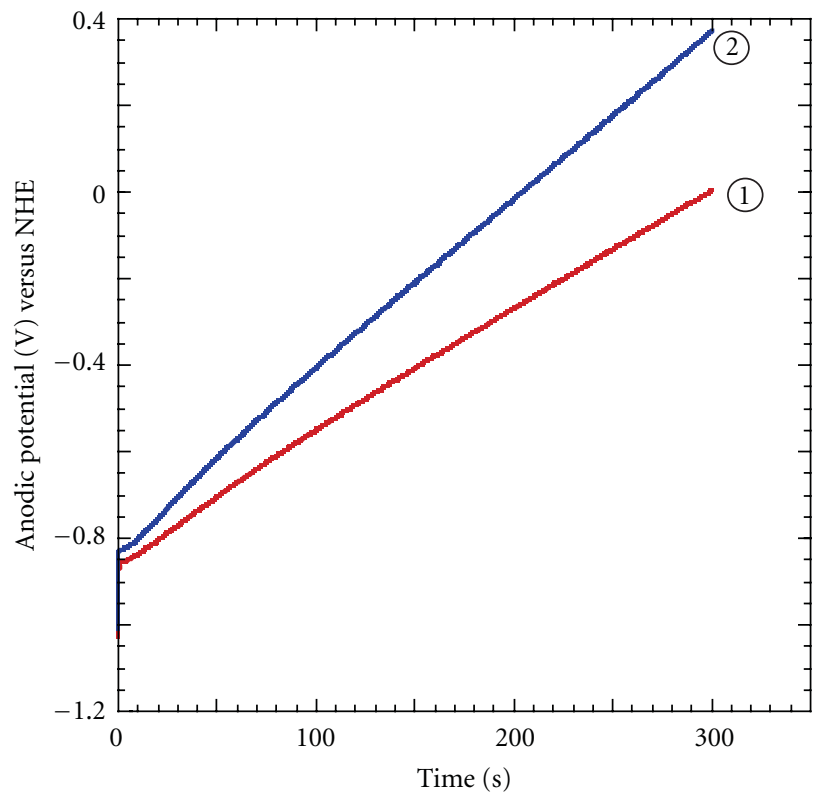

(1) Without ECAP

(2) With ECAP

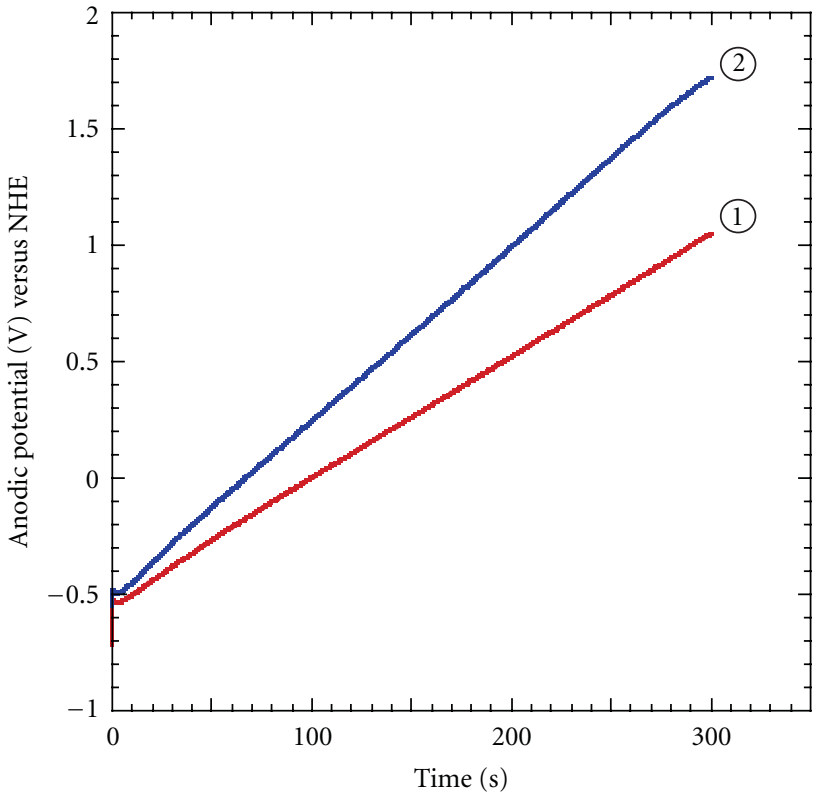

(1) Without ECAP

(2) With ECAP

(a)

(b)

FIgURE 7: Time-dependence of anodic potential of pure $\mathrm{Al}$ (a) and $\mathrm{Al}(\mathrm{AA} 1100)$ (b) at $1 \mathrm{~A} \cdot \mathrm{m}^{-2}$ in a solution containing $0.5 \mathrm{~mol} \cdot \mathrm{dm}{ }^{-3}$ of $\mathrm{H}_{3} \mathrm{BO}_{3}$ and $0.05 \mathrm{~mol} \cdot \mathrm{dm}^{-3}$ of $\mathrm{Na}_{2} \mathrm{~B}_{4} \mathrm{O}_{7}$.

at lattice defects such as grain boundaries and dislocations. As a result, the corrosion potential of $\mathrm{Al}$ (AA1100) shifted in the noble direction more rapidly than pure $\mathrm{Al}$.

In the phenomenon described above, the average oxidation rate magnitude of $\mathrm{Al}$ over the entirety of the $\mathrm{Al}$ surface is taken into consideration since it was estimated from the corrosion potential. Since pitting corrosion occurred around precipitates, it is necessary to investigate the rate of formation of Al oxide films immediately around the precipitates. In this study; however, it was assumed that the oxidation rate of $\mathrm{Al}$ around the precipitates was nearly identical to the average of the entire $\mathrm{Al}$ surface.

Since the naturally formed $\mathrm{Al}$ oxide films were of the barrier type, the anode potentials were measured using galvanostatic electrolysis in a neutral solution containing a boric salt used to form a barrier-type oxide film. Figure 7 shows the time-dependence of anode potentials of pure $\mathrm{Al}$ and $\mathrm{Al}$ (AA1100) at $1 \mathrm{~A} \cdot \mathrm{m}^{-2}$ in a solution containing $0.5 \mathrm{~mol} \cdot \mathrm{dm}^{-3}$ of $\mathrm{H}_{3} \mathrm{BO}_{3}$ and $0.05 \mathrm{~mol} \cdot \mathrm{dm}^{-3}$ of $\mathrm{Na}_{2} \mathrm{~B}_{4} \mathrm{O}_{7}$. The anode potential of pure $\mathrm{Al}$ shifted in the noble direction with increased electrolysis duration; the shift was faster with ECAP than without. The shift of the anodic potential corresponds to the rate of formation of $\mathrm{Al}$ oxide films. Therefore, it was apparent that the barrier type of $\mathrm{Al}$ oxide film was formed more quickly with ECAP than without in a neutral solution. These results wholly correspond to the time-dependence of the corrosion potentials in a $\mathrm{Na}_{2} \mathrm{SO}_{4}$ solution containing $\mathrm{Cl}^{-}$as shown in Figure 6. The pitting corrosion resistance of pure $\mathrm{Al}$ was improved by ECAP despite the fact that pure
Al contains a negligible amount of precipitates. As discussed above, this cannot be explained by a decrease in the size of the precipitates with ECAP. It can be assumed that there is a decrease in the average grain size in the $\mathrm{Al}$ matrix, and therefore the increase in rate of formation of the $\mathrm{Al}$ oxide film contributes to the improvement of pitting corrosion resistance of pure $\mathrm{Al}$ after ECAP. When the formation rate of $\mathrm{Al}$ oxide films is rapid, pits from the initial stage appear to be immediately repassivated. Authors have previously reported that the pitting corrosion resistance of Al (AA1100) and Al-Mg alloy (AA5052) was improved by ECAP [20]. The improvement of pitting corrosion resistance of pure $\mathrm{Al}$ with ECAP suggests that the decrease in the grain size of the Al matrix significantly contributes to the improvement of pitting corrosion resistance of $\mathrm{Al}$ (AA1100) and $\mathrm{Al}-\mathrm{Mg}$ alloy (AA5052) with ECAP.

3.2. Effect of ECAP on the Pitting Corrosion of Anodized Pure $A l$. The time-dependence of the anodic current density of pure $\mathrm{Al}$ and $\mathrm{Al}$ (AA1100) anodized at various current densities is shown in Figure 8. Samples were held at $1.2 \mathrm{~V}$ in a solution containing $0.2 \mathrm{~mol} \cdot \mathrm{dm}^{-3}$ of $\mathrm{AlCl}_{3}$. The anodic current density of anodized pure $\mathrm{Al}$ and $\mathrm{Al}$ (AA1100) increased rapidly after a certain period of time due to the initiation of pitting corrosion. ECAP produced no observable effect on the pitting corrosion of anodized pure $\mathrm{Al}$ at any anodizing current density. Since the anodization duration of pure $\mathrm{Al}$ was fixed at $20 \mathrm{~min}$ in this study, the thickness of the anodic oxide films increased with increased anodizing 


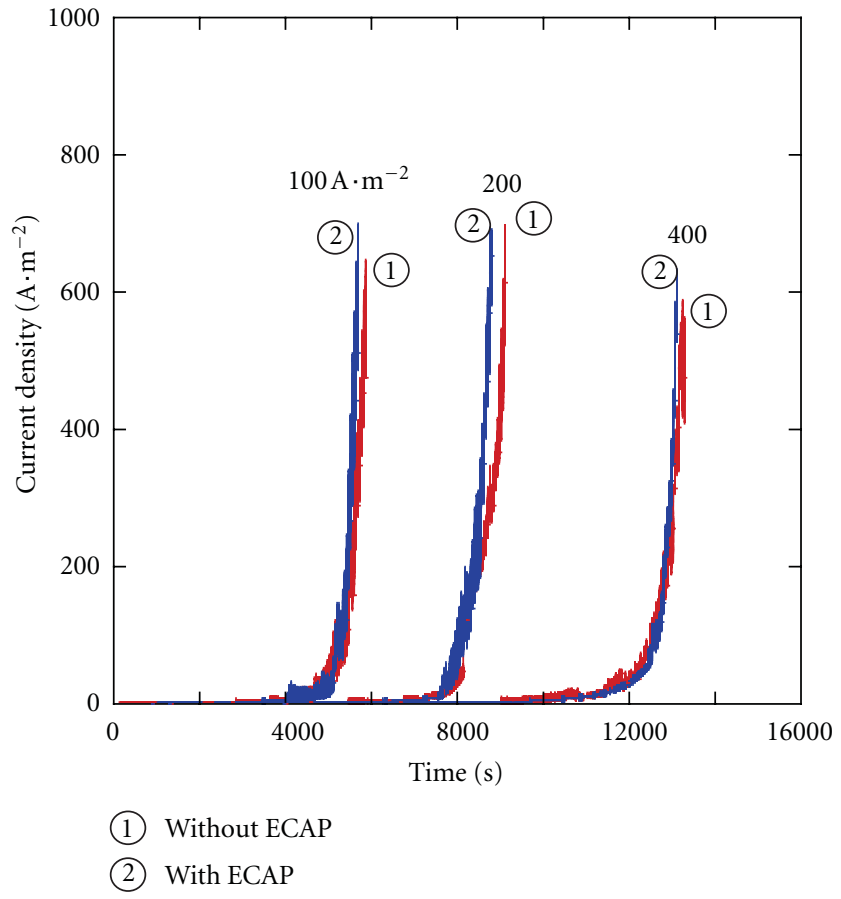

(a)

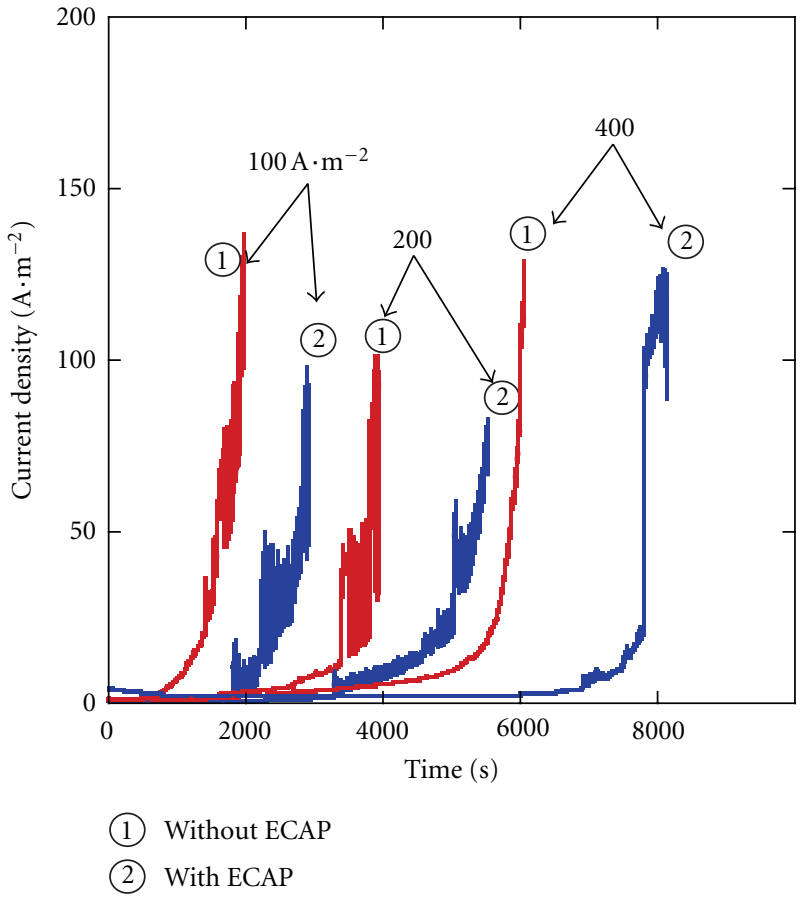

(b)

Figure 8: Time-dependence of the anodic current density of pure $\mathrm{Al}$ (a) and $\mathrm{Al}$ (AA1100) (b) anodized at 100, 200, and 400 A. $\mathrm{m}^{-2}$ while kept at a constant potential of $1.2 \mathrm{~V}$ in $0.2 \mathrm{~mol} \cdot \mathrm{dm}^{-3}$ of $\mathrm{AlCl}_{3}$ solution.

current density. Therefore, the time required for initiating pitting corrosion increased with anodizing current density. On the other hand, the time to initiate pitting corrosion of Al (AA1100) anodized for $40 \mathrm{~min}$ was longer with ECAP than without regardless of anodizing current density. This suggests that ECAP enhanced the pitting corrosion resistance of anodized Al.

Figure 9 shows SEM images of anodized pure $\mathrm{Al}$ and $\mathrm{Al}$ (AA1100). Precipitates were rarely present in the anodized pure $\mathrm{Al}$ shown in Figures 9(a) and 9(b) regardless of having undergone ECAP or not, while many small precipitates of Fe$\mathrm{Al}$ intermetallic compounds were observed in the anodized $\mathrm{Al}$ (AA1100), as shown in Figures 9(c) and 9(d). In $\mathrm{Al}$ (AA1100) without anodization, many precipitates were also present, as shown in Figure 5. In anodized Al (AA1100), the precipitates remained unoxidized and their size was smaller with ECAP than without, as shown in Figures 9(c) and 9(d). The size of precipitates in Al hardly changed after anodizing.

The pitting corrosion resistance of anodized Al (AA1100) was improved using ECAP, as shown in Figure 8. Since the size of the $\mathrm{Fe}-\mathrm{Al}$ intermetallic compound precipitates remaining in the anodic oxide films decreased after ECAP (Figures 9(c) and 9(d)) and pitting corrosion occurred preferentially around these precipitates [20], the improvement of pitting corrosion resistance from ECAP can predominantly be ascribed to a decrease in the size of the precipitates in anodic oxide films. On the other hand, there is no effect from a decrease in grain size of Al by ECAP on the pitting corrosion of anodized pure $\mathrm{Al}$ because anodized pure $\mathrm{Al}$ rarely contains precipitates. Although the natural oxidation rate of $\mathrm{Al}$ is assumed to increase due to a decrease in average grain size after ECAP, the effect of the natural oxidation rate on the formation rate of Al oxide films seems to be neglected in anodization with power supply. As a result, no effect of ECAP on the pitting corrosion of anodized pure $\mathrm{Al}$ was observed.

Within the context of this work, grain refinement of pure $\mathrm{Al}$ appears to offer significant gains in corrosion resistance in acidic and alkaline $\mathrm{NaCl}$ environments whilst having lesser, but noticeable, impact in near neutral electrolytes [15]. According to Ralston et al. [15], this illustrates that within specific material and environment combinations, grain refinement or grain coarsening may be an effective way to maximize corrosion resistance.

\section{Conclusion}

The effect of reducing the grain size of pure $\mathrm{Al}$ by ECAP on the pitting corrosion was investigated using electrochemical techniques. The potential for pitting corrosion of pure $\mathrm{Al}$ was clearly shifted in the noble direction using ECAP, producing an overall improvement in pitting corrosion resistance. It is evident from the time-dependence of corrosion and anode potentials during galvanostatic electrolysis in a neutral solution that the rate of formation of $\mathrm{Al}$ oxide films increases due to the decrease in $\mathrm{Al}$ grain size from the ECAP process. 


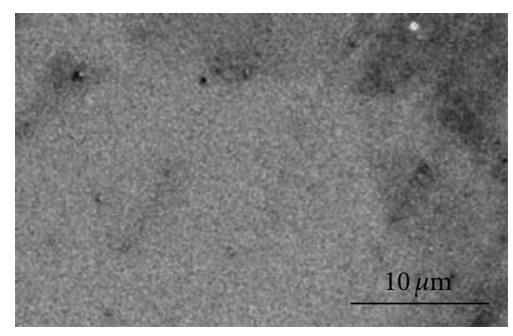

(a) Anodized pure $\mathrm{Al}$ without ECAP

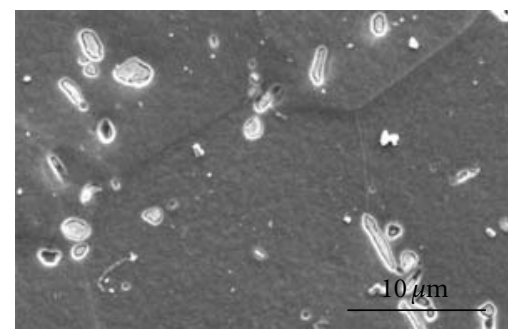

(c) Anodized Al (AA1100) without ECAP

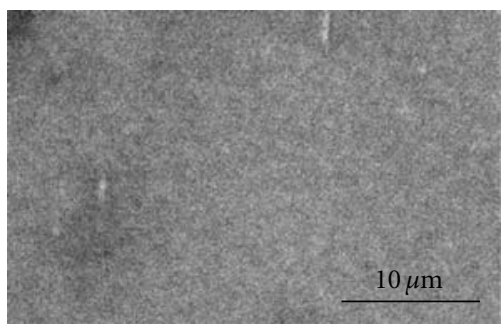

(b) Anodized pure $\mathrm{Al}$ with ECAP

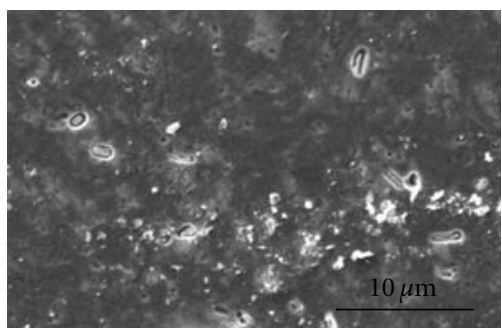

(d) Anodized Al (AA1100) with ECAP

FIGURE 9: Effect of ECAP on the morphology of pure $\mathrm{Al}$ and $\mathrm{Al}(\mathrm{AA} 1100)$ anodized at $400 \mathrm{~A} \cdot \mathrm{m}^{-2}$.

It is concluded that the improvement of pitting corrosion resistance of pure $\mathrm{Al}$ with ECAP is caused by the increased oxidation rate of $\mathrm{Al}$ since pure $\mathrm{Al}$ contains few impurity precipitates of $\mathrm{Fe}-\mathrm{Al}$ intermetallic compounds.

\section{Acknowledgments}

This study was supported by the Grant-in-Aid for Scientific Research on Innovation Areas (Research in a Proposed Research Area no. 23102505) of the Ministry of Education, Culture, Sports, Science and Technology of Japan in 2011.

\section{References}

[1] H. H. Uhlig, Corrosion and Corrosion Control, Sangyo Tosho, Tokyo, Japan, 1968.

[2] G. Ito, Corrosion Science and Engineering, Corona, Tokyo, Japan, 1973.

[3] Z. Szklarska-Smialowska, "Pitting corrosion of aluminum," Corrosion Science, vol. 41, no. 9, pp. 1743-1767, 1999.

[4] L. Fedrizzi, F. Deflorian, S. Rossi, and P. L. Bonora, "Study of aluminium filiform corrosion by using electrochemical techniques," Materials Science Forum, vol. 289-292, no. 1, pp. 485-498, 1998.

[5] S. Y. Yu, W. E. O'Grady, D. E. Ramaker, and P. M. Natishan, "Chloride ingress into aluminum prior to pitting corrosion. An investigation by XANES and XPS," Journal of the Electrochemical Society, vol. 147, no. 8, pp. 2952-2958, 2000.

[6] M. Shao, Y. Fu, R. Hu, and C. Lin, "A study on pitting corrosion of aluminum alloy 2024-T3 by scanning microreference electrode technique," Materials Science and Engineering A, vol. 344, no. 1-2, pp. 323-327, 2003.

[7] G. Bereket and A. Yurt, "The inhibition effect of amino acids and hydroxy carboxylic acids on pitting corrosion of aluminum alloy 7075," Corrosion Science, vol. 43, no. 6, pp. 1179 1195, 2001.
[8] R. Z. Valiev, N. A. Krasilnikov, and N. K. Tsenev, "Plastic deformation of alloys with submicron-grained structure," Materials Science and Engineering A, vol. 137, no. C, pp. 35-40, 1991.

[9] R. Z. Valiev, R. K. Islamgaliev, and I. V. Alexandrov, "Bulk nanostructured materials from severe plastic deformation," Progress in Materials Science, vol. 45, no. 2, pp. 103-189, 2000.

[10] J. J. Park and D. H. Shin, in Ultrafine Grained Materials II, The Minerals, Metals \& Materials Society, Warrendale, Pa, USA, 2008.

[11] Z. Horita, M. Furukawa, M. Nemoto, and T. G. Langdon, "Development of fine grained structures using severe plastic deformation," Materials Science and Technology, vol. 16, no. 11-12, pp. 1239-1245, 2000.

[12] J. Horita, "Production of ultrafine-grianed structures using equal-channel angular pressing," Journal of the Japan Welding Society, vol. 74, p. 88, 2005.

[13] Z. Horita, "Nano-structural control using severe plastic deformation," Materia Japan, vol. 41, p. 422, 2002.

[14] W. R. Osório, C. M. Freire, and A. Garcia, "The role of macrostructural morphology and grain size on the corrosion resistance of $\mathrm{Zn}$ and $\mathrm{Al}$ castings," Materials Science and Engineering A, vol. 402, no. 1-2, pp. 22-32, 2005.

[15] K. D. Ralston, D. Fabijanic, and N. Birbilis, "Effect of grain size on corrosion of high purity aluminium," Electrochimica Acta, vol. 56, no. 4, pp. 1729-1736, 2011.

[16] W. R. Osório, J. E. Spinelli, I. L. Ferreira, and A. Garcia, "The roles of macrosegregation and of dendritic array spacings on the electrochemical behavior of an Al-4.5 wt.\% Cu alloy," Electrochimica Acta, vol. 52, no. 9, pp. 3265-3273, 2007.

[17] D. Song, A. Ma, J. Jiang, P. Lin, D. Yang, and J. Fan, "Corrosion behavior of equal-channel-angular-pressed pure magnesium in $\mathrm{NaCl}$ aqueous solution," Corrosion Science, vol. 52, p. 481, 2010.

[18] N. Birbilis, K. D. Ralston, S. Virtanen, H. L. Fraser, and C. H. J. Davies, "Grain character influences on corrosion of ECAPed pure magnesium," Corrosion Engineering Science and Technology, vol. 45, no. 3, pp. 224-230, 2010. 
[19] W. R. Osório, J. E. Spinelli, C. R. M. Afonso, L. C. Peixoto, and A. Garcia, "Microstructure, corrosion behaviour and microhardness of a directionally solidified $\mathrm{Sn}$-Cu solder alloy," Electrochimica Acta, vol. 56, no. 24, pp. 8891-8899, 2011.

[20] I. J. Son, H. Nakano, S. Oue, S. Kobayashi, H. Fukushima, and Z. Horita, "Pitting corrosion resistance of ultrafine-grained aluminum processed by severe plastic deformation," Materials Transactions, vol. 47, no. 4, pp. 1163-1169, 2006.

[21] Z. Horita, T. Fujinami, M. Nemoto, and T. G. Langdon, "Equal-channel angular pressing of commercial aluminum alloys: grain refinement, thermal stability and tensile properties," Metallurgical and Materials Transactions A, vol. 31, no. 3, pp. 691-701, 2000.

[22] N. Baba, Denkaiho Niyoru Sankahimaku, Maki Shoten, Tokyo, Japan, 1996.

[23] H. Takahashi, K. Kasahara, K. Fujiwara, and M. Seo, "The cathodic polarization of aluminum covered with anodic oxide films in a neutral borate solution-I. The mechanism of rectification," Corrosion Science, vol. 36, no. 4, pp. 677-683, 1994.

[24] B. Zaid, D. Saidi, A. Benzaid, and S. Hadji, "Effects of pH and chloride concentration on pitting corrosion of AA6061 aluminum alloy," Corrosion Science, vol. 50, no. 7, pp. 1841-1847, 2008.

[25] W. R. Osório, L. C. Peixoto, M. V. Canté, and A. Garcia, "Electrochemical corrosion characterization of Al-Ni alloys in a dilute sodium chloride solution," Electrochimica Acta, vol. 55, no. 13, pp. 4078-4085, 2010.

[26] N. Birbilis and R. G. Buchheit, "Electrochemical characteristics of intermetallic phases in aluminum alloys : an experimental survey and discussion," Journal of the Electrochemical Society, vol. 152, no. 4, pp. B140-B151, 2005.

[27] W. R. Osório, L. C. Peixoto, P. R. Goulart, and A. Garcia, "Electrochemical corrosion parameters of as-cast Al-Fe alloys in a $\mathrm{NaCl}$ solution," Corrosion Science, vol. 52, no. 9, pp. 29792993, 2010.

[28] R. Ambat, A. J. Davenport, G. M. Scamans, and A. Afseth, "Effect of iron-containing intermetallic particles on the corrosion behaviour of aluminium," Corrosion Science, vol. 48, no. 11, pp. 3455-3471, 2006. 

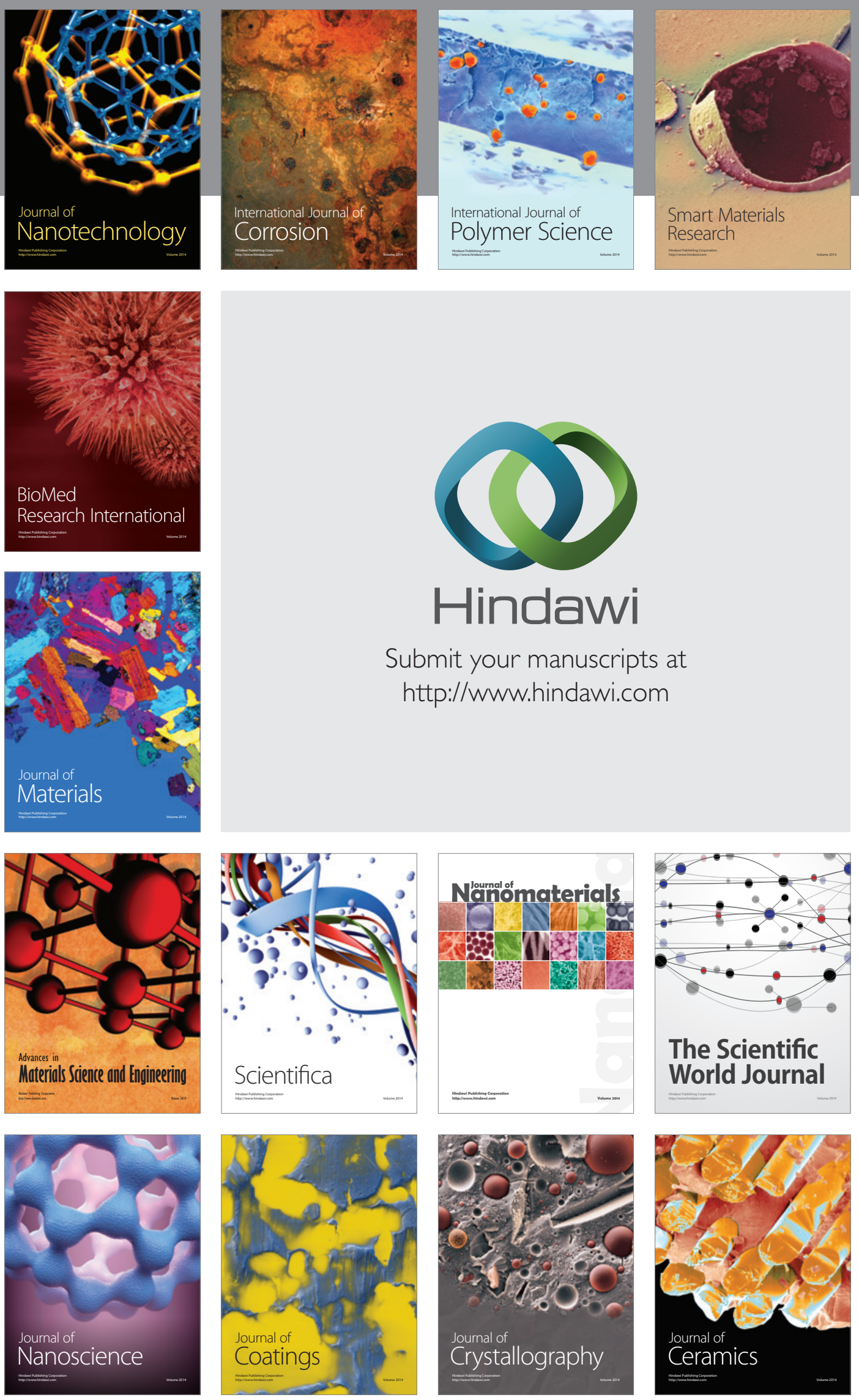

The Scientific World Journal

Submit your manuscripts at

http://www.hindawi.com

\section{World Journal}

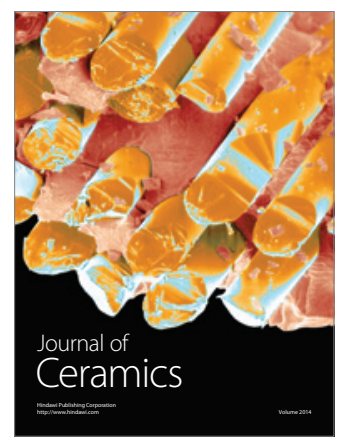

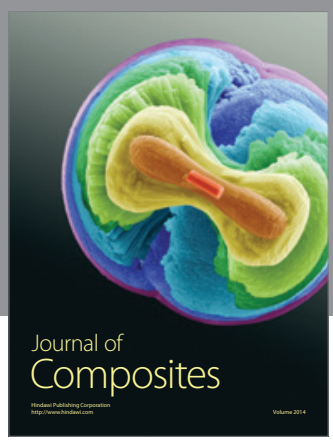
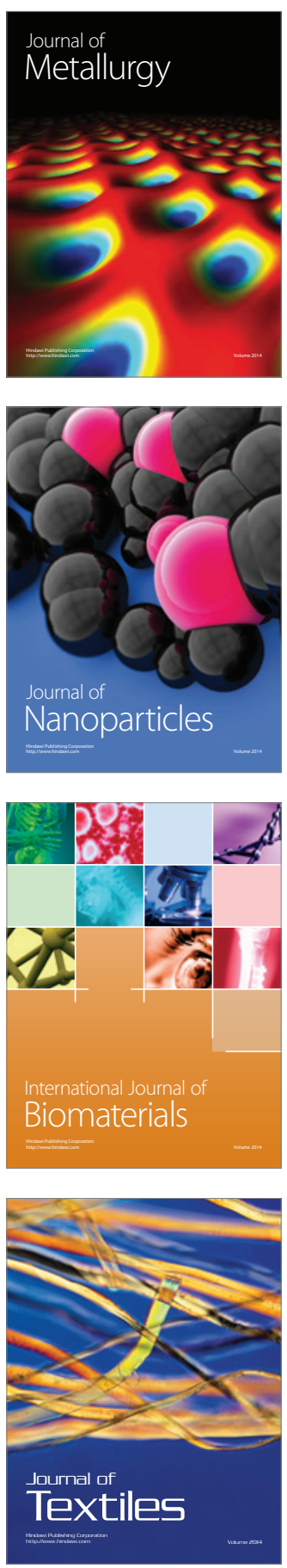